DOI: 10.7596/taksad.v3i2.332

\title{
Psiko-Sosyal Açıdan İnönü Dönemi Dinî Hayatla İlgili Bazı Değerlendirmeler*
}

\section{Zeynep Özcan ${ }^{1}$}

\section{Öz}

Bu çalışmanın amacı "Millî Şef” ya da “İnönü Dönemi” olarak da bilinen 1938-1950 yılları arasında yaşanan dinî hayatı temel dinamikleriyle ortaya koymak ve günümüze yansımalarını psiko-sosyal açıdan değerlendirmektir. Bu kapsamda öncelikle dinî hayatın içinde yaşandığ hayatın portresi çizilerek günümüz dindarlığına yansımaları ele alınmıştır. Önemli bir değişim ve dönüşümün yaşandığı bu yıllarla ilgili elde edilen veriler, dönemi yaşayanlarla yapılan mülakatlar ile zenginleştirilmiş̧tir. Neticede dönemin dinî hayatının, içinde bulunduğu sosyokültürel atmosferden büyük oranda etkilendiği, ancak buna rağmen kendi içinde bir gelişim seyri takip ederek günümüz dindarlığına yansıdığı ve bazı açılardan her iki dönem arasında benzerlikler bulunduğu görülmüştür.

Anahtar Kelimeler: Cumhuriyet dönemi, İnönü dönemi, Din, Dindarlık, Dinî hayat.

\footnotetext{
* Bu makale, “Cumhuriyet Dönemi Dinî Hayat (1938-1950)” isimli doktora tezinden yararlanılarak hazırlanmıştır.

${ }^{1}$ Yard. Doç. Dr., Karabük Üniversitesi İlahiyat Fakültesi. zeycankan@hotmail.com
} 


\title{
Some Evaluations About Religious Life of Inonu Period in Terms of Psycho-Sociology
}

\begin{abstract}
The aim of this study is to reveal the religious life during the period known as "National Chief" or "Inönü Period" between the years 1938-1950 with all its dynamics and to probe its reflections to the present from psycho-sociology perspective. Within this scope, first of all, some information about the environment, in which the religious life was lived, has been given. Later, its reflections have been discussed by describing the religious life which was shaped by that environment. The data related with that period when an important change and transition happened has been enhanced by the interviews held with the people who lived during that period. As a result, it has come out that religious life of that period had been affected to a great extent by socio-cultural, socio-economic and socio-political atmosphere; however, it has reflected on the religiousness perception of the present by following an improvement progress in itself. Also, it has been seen that religiousness perception of that period and today's world has some similarities.
\end{abstract}

Key Words: Republic period, Inonu, Religion, Religiousness, Religious life

\section{GíRiş}

Bugün ancak dün ve yarın arasında mana kazanan bir geçiştir (Safa, 2011:113). Bugünkü ve yarınki nesillerin, kültür kodlarının hangi süreçlerden geçerek kendilerine ulaştığını anlayabilmeleri için, mazideki yaşanmışlıkları iyi tahlil etmeleri gerekir (Yalçıntaş, 2012:9). Çünkü mazi, bireye, bugünü ve geleceği anlama konusunda olağanüstü berrakl1kta bir perspektif kazandırmaktadır (Türköne, 1994:Takdim). Dünden gelen birikimlerle geleceği öngören ve bugününü yaşayan insanın hayatını doğru anlamlandırabilmesi, geçmişteki yaşanmışlıklarının üzerindeki etkisi nispetindedir (Okumuş, 2002:54). Bu nedenle günümüzün dindarlık algısının izlerini geçmişte sürmek adına tarihe yönelmek, bu çalışmanın temel yaklaşımını oluşturmuştur.

Yakın Türk tarihinde “Millî Şef” ya da “İnönü Dönemi” olarak da bilinen 1938-1950 yılları arasında yaşayan Türk toplumunun dinî hayatı ve bu hayatın günümüz insanının dinî 
duyuş, düşünüş ve davranışına etkileri çalışmanın temel problemidir. Yelpazesi oldukça geniş olan bu konunun psikolojik, sosyolojik ve sosyal psikolojik boyutları vardır. Psikolojinin temel probleminin insanı anlama çabası olduğu düşünüldüğünde (Topçu, 2008:38), bu çabanın, insanın ait olduğu toplumla ilişkilerine inmeden bir sonuca varamayacağı açıktır (Delay and Pichot, 1975:22). Sürekli birbiriyle etkileşim halinde olan insan ve toplumun, bir paranın yüzleri gibi olduğu, dolayısıyla birbirinden bağımsız ele alınıp incelenemeyeği, çünkü insanın şahsiyetinin içinde yetiştiği toplumun inanç, değer, norm ve tutumlarıyla şekillendiği bilinen bir gerçektir (Kuşat, 2001:107). Böylesi bir durumda yani birey psikolojisinin daha başından toplum psikolojisi kimliğine büründüğü bir durumda, bu ikisinin kesin çizgilerle birbirinden ayırt edilemeyeceği gerçeği (Freud, 2006:13), çalışmaya daha çok sosyal psikolojik bir boyut kazandırmaktadır.

Araştırmada arşiv araştırması yöntemi kullanılmıştır. Hazır bilgiden yararlanma ve soru sorma tekniklerininin kullanıldığg çalışmada mümkün olduğunca birinci el kaynaklara inilip elde edilen bilgiler üzerinde analiz yapılmaya çalışılmıştır. Yakın tarihle ilgili bir araştırma olduğu için dönemi yaşayan kişilerle yapılan mülakatlar, o dönemde yaşananların aydınlatılması açısından araştırmaya 1şık tutmuştur. Biyografik ve otobiyografik eserlerin yanısıra son dönemlerde yayımlanan ve konuyla ilgisi bulunan bazı dergi ve gazete makalelerinden de istifade edilmiştir.

\section{SOSYO-KÜLTÜREL PERSPEKTIFTEN 1938-1950'Lİ YILLARDA TÜRKIYYE}

Dinî yaşayış ve davranışa, fizyolojik ve psikolojik süreçlerin yanısıra tüm toplumsal faktörlerin katkıda bulunduğu bilinen bir gerçektir. Dinin muhatabı olan insanı olumlu veya olumsuz yönde etkileyen herhangi bir faktör, dinî inançların insanlar tarafindan içselleştirilmesi ve davranış özelliklerine dönüşmesi sürecini doğrudan etkilediği için, insanları etkileşim alanlarından soyutlayarak doğru ve eksiksiz bir şekilde anlamak mümkün değildir (Bahadır, 2010:94, Göka, 2011:203, Karaca, 2001:19, Karacoşkun, 2006:7, Kurt, 2009:3). Bu nedenle, araştırmanın bu başlığında, çalışmaya konu olan dönemde yaşanan dinî hayatın etkileşim halinde olduğu, hatta içerisinde şekillendiği sosyo-kültürel atmosfer hakkında bilgi verilecek ve bu bilgi çerçevesinde o günkü toplumun hangi şartlar içerisinde yaşadığının resmi çizilecektir.

\section{Dönemin Sosyo-Kültürel Durumu}

Kültür, tıpkı Cumhuriyetin ilk yıllarında olduğu gibi 1940'l1 yıllarda da önemle üzerinde durulan, hatta bir kalkınma problemi olarak ele alınan önemli bir meseledir. Ancak 
bir önceki dönemden en büyük farkı, artık bir bütünleştirme aracı olmaktan çıkıp açık bir çekişme alanı haline dönüşmesidir (Subaşı, 2004:82-83).

Geleneksel kültürün temel değerlerinin modern Cumhuriyet ilkelerini kökten sarsabileceği kaygısı, daha önce izlenen milli kültür politikalarından vazgeçilip yerine humanist bir kültür anlayışının benimsenmesi sonucunu doğurmuştur (Yiğit, 1992:42-43). Türkiye'de 1938'den sonra resmi bir politika olarak benimsenen ve dönemin kültür politikalarına damgasını vuran hümanizm, Tanrı merkezli sosyal ve kültürel hayat yerine, insan merkezli bir kültürel hayatı öngörmektedir. Yönetim tarafından "eski Yunan ve Roma Medeniyetine inmek” şeklinde tarif edilen bu anlayışın, Yunan kültürüyle Türk kültürünü kaynaştırarak Türk hümanizmini oluşturmayı hedeflediği ve bu şekilde beklenen gelişmeyi sağlayabileceği düşünülmektedir (İlhan, 1982:228-229, Şeker, 2000:13, Özdenoğlu, 1945:4045). Türkdoğan'ın ifadesiyle tarihi Türk-kültür kodlarından çıkarılarak Greko-Romen kaynaklarına yönelmeyi esas alan (Türkdoğan, 1996:14) ve bu yönüyle inkılapçı bir dinamizm kazanan İnönü dönemi kültür politikalarının temel yaklaşımına göre: Ülkenin kalkınmaya ihtiyacı vardır. Kalkınmak için Batılılaşmak, Batılılaşabilmek için de Batının kültür kaynaklarına inmek gerekir. $\mathrm{Bu}$ mantık beraberinde, kalkınmayı başarabilmiş toplumların kültürlerinin yüksek kültür olduğu anlayışını doğurduğu için bizim de kültürel olarak kalkınabilmemiz, Batının bu yüksek kültürünün alınması ve nesilden nesile aktarılması şartına bağlanmıştır (Karatepe, 1997:90, Turhan, 1972:13, Yiğit, 1992:43).

Batılı kültür çevresine “mensubiyet”in, kalkınmanın ve medenileşmenin tek yolu olduğu vurgulanan bu dönemde, bu “tek yol”un İslami kültürle tıkanmaması için, laiklik son derece katı ve dine karşı bir tavır olarak uygulanmıştır. (İlhan, 1982:228-229, Yiğit, 1992:43) Hümanist düşünceyi Türk aydınlar arasında ilk defa dile getirenlerden Yahya Kemal Beyatlı'nın ifadeleri, bu yaklaşımın nedenini açıklar niteliktedir:

"Esasen biz, coğrafya ve kısmen de medeniyet bakımından Yunanlıların vârisi sayılırdık; bu verasetin Avrupa'da meydana getirdiği sonuçları yaşamamızı din engellemiş ve bu hal 1850'lere kadar devam etmişti. Aslında yapılacak şey, bütün Avrupa medeniyetinin kaynağı olan Yunan medeniyetine yönelmekti... Çünkü Avrupa edebiyatlarının hiçbirini asıl kaynaklarına, yani Yunan'a ve Latin'e gitmeden anlamak mümkün değildi." (Elbir ve Karakaş, 2007:382)

Dönemin önde gelen yazar ve mütercimlerinden olup düşünceleriyle kültür politikalarına yön veren bir isim olan Nurullah Ataç, tam anlamıyla Batılılaşabilmek için Batının ruhunun içimize tam anlamıyla sindirilmesi gerektiğini düşünmektedir (Ataç, 1957:53-54). Devrimden kastedilen şeyin ülkeyi Batı ülkelerine benzetmek olduğuna inanan 
Ataç'la aynı görüşleri paylaşan Karaosmanoğlu'da, Avrupayı Avrupa yapan gücün "gökten ilham alan birtakım rasullerde" değil, Eflatun'unun felsefesinde Aristokratalis'in mantığında, Homeros'un şiirinde, Evripid'in ve Sofokles'in tragedyalarındaki derinlikte olduğuna inanmaktadır (Karaosmanoğlu, 1940:327).

Benimsenen humanist anlayış çerçevesinde kültürün en önemli manevi unsurlarından olan din, dil ve tarihin bu dönemde yeniden yorumlanarak maddeci bir temele oturtulmak istendiği görülmektedir (Turan, 2005:123). Zira sonuçları günümüze kadar uzanan bu değişim sürecinde en güçlü mukavemetin ve muhalefetin dinden geleceği düşünüldüğünden bu dönüşüm sırasında kimlik, otorite ve sadakate dair eski İslami kavramların yerine Avrupa kaynaklı yeni kavramların geçmesi yaşamsal bir önem taşımaktadır. Çünkü dinî ve millî mukavemeti kırmadıkça ve etkilerini en aza indirgemedikçe güçlü bir değişimin olamayacığı bilinmektedir. Ancak bu değişim sürecinde dinin etkisi birden değil aşamalı olarak kırılmalıdır. İslamiyet'in kuramsal olarak oluşturulmuş devlet sistemindeki Tanrı'nın yeri, önce millet, sonra da hümanist kültürle doldurulacaktır. (Turan, 2005:105, Lewis, 2009:658). Süleyman Çelebi’nin Peygamberimiz için yazdığı Mevlidi, Behçet Kemal Çağlar'ın “Bizim Mevlüt" başlığı altında millîyetçi ideolojiye göre yeniden yazması, Lewis'in bu tespitini destekler niteliktedir. 1942 yılında Yücel dergisinde yayımlanan yeni mevlide göre:

"Millet àdın zikredelim bir kere

Vâcip oldur cümle işte Türklere;

Şevk ile 'Türküm' dese bir dem lisan

Dö’külür cümle hüzün misli hazan;

İsmi pâkin pâk olur zikreyleyen

Her murâdà erişir 'Türküm' diyen...

Ger dilersiz bùlasız şevku necat

A’tatürkè A’tatürkè esselat.” (Çağlar, 1942:19)

Millîyetçiliğin bir din haline dönüştürülmeye çalışılmasının sembolü olabilecek bu tür aşırılıklar, Tekinalp'in “Kemalizm bir tek tanrıya tapmıştır: Ulusalcılık” (Tekinalp, 1998:50) sözüyle gelmiş olduğu noktayı göstermesi bakımından oldukça anlamlıdır. Yine Behçet Kemal Çağlar'ın "Dinimiz” adlı bir kitapla ilgilli olarak yaptığı değerlendirme dikkat çekicidir:

"Kemalizmi yalnız dövizlere, rakamlara, nizamname veya programlara emanet edip geçemeyiz. Onu bir iman halinde içe sindirmek ve bütün nesillere benimsetmek gerektir” (Çağlar, 1940:3). 
1945 yılında Türk Dil Kurumu tarafından yayımlanan Türkçe sözlükte, “din”in, “inanılıp çok bağlanılan fikir veya ülkü” olarak izah edilip, “din” kelimesi karşısında "Kemalizm Türkün dinidir" ifadesine yer verilmesi de, bu konuda gelinen noktayı göstermesi bakımından anlamlıdır (Türk Dil Sözlüğü, 1945:153).

Devletin biçimlendirdiği millî din anlayışından sonra sıra, yapılacak değişikliklerle “dini ve Allah’1 aydınlanma felsefesindeki yerine koymaya gelmişti” (Perinçek, 2007:25). İlk önce dilde köklü değişiklikler yapılması planlanmıştır. Çünkü dil devrimi, kayıtsız şartsız Batılılaşma ve Doğu ile her türlü köprüleri atma anlayışının hakim olduğu bir umumi tasfiye hareketinin bir parçası olarak görülmektedir (Banguoğlu, 1984:145, Kocabaş, 2009:287-289). $\mathrm{Bu}$ nedenle toplumu sekülerleştirmede bir vasıta olarak görülen, dilde uhreviliği, semaviliği hatırlatan her şeyin yerine yeni anlamlar konulmaya çalışılarak, dinî değerlerin gözden düşürülmesi ve insan hayatının dünyevileştirilmeye çalışılması, bu dönemin en dikkat çekici çabaları içerisinde yer almaktadır (Tarhan, 2010:86-87).

Dönemin kültür politikaları çerçevesinde tarihe verilen yer de, humanist anlayışın sınırları içerisinde kalmıştır. Zira Atatürk döneminde, Türk tarihinin Osmanlılar döneminde ihmal edildiği düşüncesi ile okullarda özellikle Türk tarihi ağırlıklı tarih kitapları okutulurken, İnönü döneminde, ağırlıklı olarak Avrupa tarihi, ders kitaplarına konu olmuştur. Bu duruma örnek olarak, 1947'de yazılmış olan “Tarih I” adlı lise ders kitabı gösterilebilir. Adı geçen kitabın içeriğine bakıldığında \%40 Yunan tarihi, \%40 Roma tarihi, \%8 Eski Anadolu tarihi ve $\% 8$ oranında da diğer konulardan bahsedilirken, Türk tarihinin kitap içerisindeki oranı \%4 olarak göze çarpmaktadır (Şeker, 2000:78).

Cumhuriyetin devrimci kuşağı, devrimleri topluma tümüyle yerleştirmenin yolunun ancak eğitim ve kültür yoluyla olabileceğini düşündügüünden Köy Enstitüleri gibi örgün eğitim kurumlarını bu uğurda eşsiz bir vasıta olarak görümüştür (Kalkanoğlu, 1991:160). Nitekim Makal'a göre, Köy Enstitüleri, bu dönemin "hayattan bıkmış, dünyadan bütün ümitlerini keserek bir softanın peşinde hayali ve meçhul bir aleme bağlanmış” insanımıza yeni bir yaşam anlayışı götürülmesi için açılmış kurumlardır (Makal, 2009:8). İrticaya ve taassuba karşı yürütülen mücadelenin mekanı olarak gösterilen Köy Enstitüleri, öğrencilerini pozitif aklın öğretileri doğrultusunda yetiştirmeyi hedeflemiştir (Dikici, 2008:181). Zira bu kurumun mimarı olan İsmail Hakkı Tonguç, imanın yerine aklı hakim kılmayı hedefleyen politikasını şu sözlerle özetlemiştir:

“Ümid edelim ki, yarının dünyası, imanını göklerden gelecek görünmez kuvvetlerle ve fizik ötesi fikirlerle beslemesin. Eğer onun kuvvetli ve mesut bir temeli olsun istiyorsak biz insanlar yeni 
dünyaya şamil, ihtirassız, yalansız, insani, rasyonel ve reel taze bir din vermeliyiz. Köy Enstitüleri'nde yetiştirilen çocuklar, skolastiğe köle olmaktan kurtarılmaya çalışılmıştır.” (Başaran, 2003:32)

Bu sözlerden de anlaşılacağı üzere "din ahlakının yerine iş ve bilim ahlakını getirmek, iş saygısını, ortak ve yeni bir din gibi” kabullenmek, Köy Enstitüsü kurucularının ana ilkelerinden birisi olmuştur (Eyüboğlu, 1999:76). Bu nedenle de Köy Enstitüsü programında dine yer verilmemiştir. Çükü ancak bilimsel esaslara uygun olarak eğitilmiş, akıl ve mantığını inanç sistemlerinin önüne almasını bilen öğretmenlerin (Öklem, 2008:374) devrim aracı olarak kurulan bu kurumlarda (Kirby, 2010:379) devrimin bütün dinamizmini yüklenip, sarıklı köy hocalarının yerini alabileceklerine inanılmaktadır (Tonguç, 1947:419).

Devletin resmi kültür politikalarını sadece şehirlerde değil köy ve kasabalarda yaşayan tüm halka aşılayabilmek için Halkevleri ve Halkodaları gibi yaygın eğitim kurumlarının birer vasıta olarak kullanıldığı görülmektedir (Koçak, 1996:104-105, Zeyrek, 1987:32-33). Bu kurumlarda hümanist, laik eğitim politikalarının ve din kavramını yadsıyan Kemalist tarih felsefesinin (Köşgeroğlu, 2010:50-103) bir gereği olarak dinî duyguları hatırlatacak, ve bu alandaki bilgileri yeni nesle öğretecek hiçbir faaliyete asla müsade edilmemiştir (Alkan, 1989:183). Çünkü İslami geleneğin, tıpkı Köy Enstitüleri gibi halkevlerinde de giyimiyle, konuşmasıyla, bilinciyle, beğenisiyle, dünyayı algılayış biçimiyle ve yaşam anlayışıyla yaratılmak istenen yeni insan modelinin önündeki en büyük "engel” olduğuna inanılmaktadır (Yıldırım: 1995:86). Bu nedenle Osmanlıcılığa da karşı olan bu kurumların yayınlarında, sıklıkla Osmanlı'ya ve saltanat yıllarına karşı kuvvetli eleştiriler yer almıştır. Yeşilkaya’ya göre Osmanlı geleneğine ve dinin katı kurallarına karşı modern bir laik yaşam modelinin savunulduğu bu kurumlarda "Asırların sakat din telakkileri” ile mücadele esas alınmıştır (Yeşilkaya, 2011:115-117).

Eğitim gibi sosyo-ekonomik düzeyin de dinî yaşayış üzerinde etkili bir unsur olduğu, bireylerin gelir durumlarının ve buna paralel olarak sürdürdükleri yaşam tarzının, onların fikir dünyalarını ve olaylara bakış açılarını önemli ölçüde etkilediği bilinmektedir (Argly and Hallahmi, 1975:161, Taş, 2004:79). Dönemin sosyo-ekonomik durumu halkın sadece dindarlık düzeyi değil aynı zamanda siyasi tercihi ve psikolojik sağlığı üzerinde de etki yapan bir niteliğe sahiptir. Nitekim gerek birey gerekse toplumsal anlamda yaşanan tüm değişimlerin temelinde, dönemin ekonomik politikalarının ve bu politikaların sonuçlarının etkisi hissedilmektedir.

Katı devletçi politikalarla yönetilen dönemin Türkiye’sinde ekonomik alanda çok ciddi sıkıntılar yaşandığı, ekmek gibi en temel besin maddesinin bile karneye bağlandığı ve 
halkın fedakarlığının neredeyse geçim kaynağı haline dönüştüğü görülmektedir. Ekonomik olarak zor geçen bu yıllarda ağır vergi yükü altında ezilen insanların aynı zamanda bulaşıcı hastalıklar ve yıkıcı depremlerle mücadele ediyor olmalarına bir de savaş kaygısının eklenmiş olması, yaşanan bu olumsuz tabloyu iyice ağırlaştırmıştır (Boratav, 1989:85, Goloğlu, 1974:59-60). Dönemin iaşe müsteşar yardımcısı Aydemir'in anlattı̆̆ına göre yetersiz beslenme, açlık ve yoksulluğun çoğunluk için neredeyse hayat tarzı haline dönüştüğü ve açlıktan ölüm vakalarının gittikçe arttığı bu yıllarda, yaşanan yokluk ve sefalet, devlet görevlilerine intiharı bile düşündürecek boyuttadır:

“... İşte bu şartlar içinde ve günlerden birindeydi ki, bir sabah çok erken saatlerde vekil Mümtaz Ökmen'i (Ticaret vekili) evinde görmem icap etti. Gözleri kan çanağ 1 gibiydi ve belli ki uykusuz, yorgun ve belki de hastaydı. Tarif edemeyeceğim bir ruh hali içinde ve hiç bir önsöze lüzüm görmeden şöyle konuştu: - Şevket bu gece hiç uyumadım. Bu salonun içinde bir uçtan bir uca dolaştım durdum. Biliyor musunuz ne düşündüm? Düşündüm ki, şu balkona çıkayım ve oradan kendimi sokağın taşları üzerine atayım. Yalnız üzerimize aldığımız şu yükten kurtulmak için değil, millet dediğimiz, ordu dediğimiz son varlıklarımıza karşı, şu ülkede ve hele bu asırda, bu kadar aciz ve çaresiz kaldığımız için!...” (Aydemir, 1993:202-204, Sakal, 2008:22).

Kültür ve ekonomi alanlarında olduğu gibi dış dünyada yaşanan gelişmelerin de dönemin dinî hayatı üzerinde etkisi olduğu muhakkaktır. Zira bu alanda yaşanan gelişmeleri ABD ve SSCB arasında cereyan eden soğuk savaştan bağımsız bir şekilde ele almak mümkün değildir. Türkiye'nin dişardan görünümünü çok önemseyen İnönü’nün (Toker, 1970:148) 2. Dünya Savaşı esnasında uyguladığı politikalarla ülkenin bağımsızlığını ve toprak bütünlüğünü korumayı başardığı görülmektedir (Ekincikli, 2008:419-420). Ancak buna mukabil oynanan denge oyunu sonucu (Deringil, 1994:3-5, Koçak, 1996:701) yaşanan diş dünyadan tecrit edilme tehlikesi, toprak bütünlügünü tehdit eden birtakım gelişmelerin yaşanmasına yol açmıştır. $\mathrm{Bu}$ durum karşısında sığınacak bir liman arayan Türkiye'nin yardımına koşan Amerika ise, yaptığı yardımlar karşılığında ülkenin iç ve dış siyasetine yön veren bazı taleplerde bulunmuş, ${ }^{2}$ bu talepler sonucunda siyasi ve ekonomik anlanda daha liberal bir çizginin benimsemesinde etkili olmuştur (Sakal, 2008:28). Bu etkinin bir sonucu olarak dinî özgürlükler ve dinî eğitim konularında büyük bir rahatlamanın yaşandığ1 görülmektedir. (Kongar, 2013:92,176-186, Yalçıntaş, 2012:54-86).

\section{DÖNEMIN DİNDARLIĞINA GENEL BAKIŞ}

\footnotetext{
${ }^{2}$ İç siyassette liberal bir anlayışın benimsenmesini şart koşan Amerika, Türkiye'nin Sovyetler'e karş1 ileri bir karakol vazifesi üstlenmesini istemiştir. Örneğin Amerika, Sovyetler'i tehdit eden nükleer başlıklı Jüpiter füzelerini Türkiye'de
} 
Dönemin resmi ideolojisine göre din, çağdaş ve kalkınmış bir devlet olmak isteyen Türkiye Cumhuriyet'nin önünde bir engel olarak telakki edildiği için, toplum üzerindeki belirleyici gücününün bertaraf edilmesine yönelik politikalar geliştirilmiştir (Coşkun, 2005:97-99). Bu politikalar belirlenirken dinin tamamen ortadan kaldırılmasından ziyade, ulus devlet sınırları içerisinde bir "ulusal din” geliştirme gayretiyle bir "Türkiye İslamı" yaratılmak istendiği görülmektedir (Atay, 2011:53, Hizmetli, 2003:399). Bu şekilde hem modernleşme sürecine katılmak kolaylaşacak, hem de modernleşme değişimine direnen dinin, direnci kırılarak pasifleştirilecektir (Yıldırım, 1999:112-113). Eski haliyle "fazileti vuran küflü bir silah” olarak görülen din (Arar, 1969:80), kendisine kazandırılan bu yeni formla, "çağdaş uygarlık düzeyine" ulaşmada bir engel olma durumundan da çıkmış olacaktır. Bütün bu gelişmeler yaşanırken din ile devlet işlerinin birbirinden ayrılması şeklinde tanımlanan laiklik ilkesinin, dini, toplum hayatından, ferdin günlük davranışlarından, hatta mümkünse zihninden ve ruhundan çıkartıp atmanın bir aracı olarak benimsendiği görülmektedir. Bazı çevrelerce din düşmanlığı şeklinde anlaşılan bu anlayışın, on dokuzuncu yüzyıl pozitivizminin ağır etkisinde olduğu, bu nedenle de din-dışı/sekülerlik ve dine-karşı/atezimle özdeşleştirildiği ileri sürülmektedir (Bulaç, 2012:55-84).

İnönü yönetiminin dine olan bakışı, dinî hayatla ilgili birtakım kanuni düzenlemeleri de beraberinde getirmiştir. Çünkü idari kadroya göre din, ancak kul ile Allah arasındaki bir ilişkiden ibarettir ve bu ilişkinin yaşanacağı yer de yalnızca bireylerin vicdanıdır. Laiklik ilkesi gereği dinin, sosyal hayatta herhangi bir yansıması olamaz. Olması durumunda ise çıkarılan yasalarla bu durum ortadan kaldırılmalıdır (İnönü, 1996:258, Muallimler Birliği Mecmuas1, 1925:150, Yücel, 1974:84,143). Dönemin idareci kadrosuna hakim olan bu anlayış, başlangıç tarihi önceki döneme ait bazı düzenlemeler de dahil olmak üzere, pek çok yasal tedbirin alınması ve tepkilere rağmen bu tedbirlerin uygulanması sonucunu doğurmuştur. Arapça ezan okuyanların cezalandırılmasına yönelik kanuni düzenleme yapılması, dilde özleşme adı altında Arapça ifadelerin, dolayısıyla Kur'an eğitiminin yasaklanması ve özellikle dinî basının kanunla kontrol altında tutulmaya çalışılması bu uygulamalardan bazılarıdır (Resmi Gazete, 1941, Feroze, 1995:34, “Tarihi Vesika”, 1959:144).

İnönü hükümetlerinin “dinî ibadetlere karşı çatık kaşlı tutumu”, insanların zihninde 'bu dönemde din düşmanlığı yapılmıştır' algısının yerleşmesine yol açmıştır (Karpat,

konuşlandırmış, Küba krizi sırasında Sovyetler'in oradaki füzelerini geri çekmelerine karşılık, Amerika'da bunları geri çekmişti. (Kongar, 2013:185) 
2009:266). Özellikle 1945 yılına kadar yaşanan süreçte dinî alanla ilgili uygulamalara bakıldığında, bu dönemin, gerçekten de din ve vicdan hürriyetinin askıya alındığı yasak bir dönem olarak yaşandığı söylenebilir. Laiklik ilkesinin din karşıtlığ1 anlamına büründüğü bu dönemde (Armağan, 2010:45, Gerger, 1991:198-219), insanların en temel hakları olan inanma hürriyetlerinin çeşitli boyutlarıyla kesintiye uğraması, kalplerde ve zihinlerde derin izler bırakacak türdendir. Nitekim laiklik ve milliyetçilik ilkeleriyle ilgili yasal düzenlemeler gerekçe gösterilerek Kur'an öğreniminden ve din eğitiminden mahrum bırakılan halk, Arapça ezan yasağıyla camilerden uzaklaştırılmış, hacca gitmeleri engellenmiş, dinî yayın neşretmeleri yasaklanmış, dinî bir cemaat halinde toplanmaktan menedilmiş ve sonuç olarak tam da hedeflendiği gibi vicdanlara hapsolmuş bir dinî yaşamla başbaşa bırakılmıştır (Başgil, 2009:196, Gerger, 1991:184, Öcal, 2008:27-28, Y1lmaz, 1998:197).

Tüm yasak ve sınırlamalara rağmen dönemin karmaşık ortamında insanların yaşamlarını yoluna koyabilmek için dine bir ümit 1şığı olarak sarıldıkları ve gizli de olsa canlı bir dinî hayatı yaşadıkları yönünde birtakım tespitler vardır (Mardin, 2010:82-83, Lewis, 2009:569570). Politik atmosfer nedeniyle dönemin insanının dine doğru anlam atfetme imkânı bulamasa da özellikle kırsal kesimde onu ciddiye alma düzeyinin oldukça yüksek olduğu söylenebilir. Anlaşılan o ki Cumhuriyet Türkiye'sinde dinî düşünce ve yaşam tarzı bakımından geliştirilen yeni dinî anlayışın etkisi, sadece laik olan üst tabakayla sınırlı kalmış, köylere pek ulaşmamıştır (Karpat, 2010:365). Zira mülakatlar esnasında dönemin dinî hayatına ilişkin tespitlerin dönemin şahitlerinin ifadeleriyle de desteklendiği görülmüştür. Örneğin 1932 doğumlu Mücibe Kılıç’a göre:

"Yasaklara rağmen kimse dininden vazgeçmedi. Baskı oldukça inancımız daha da güçlendi, dinimize daha çok bağlandık. Çünkü kökümüz İslam. Kalktık ailelerimizden bu terbiyeyi aldık. Bu yüzden yasak çözüm değildi. Çünkü insan kendi hayatıyla ilgili kararı yine kendisi veriyor. Ama can korkusundan dinden uzaklaşanlar da olmuştur tabi."

O dönemde Erzurum'un bir köyünde yaşayan Mücibe Kılıç, bulunduğu bölgede yaşanan dinî hayat hakkında şu bilgileri vermiştir:

“Köylerde şeyh çoktu. 24 saat ahır odalarında bacalar kapatılarak ders yapılırdı. O dönemde insanların şeyhlere verdiği değeri şimdi insanlar Allah’a vermiyor. Çünkü o şeyhler bize dinimizi öğretiyordu. İnsanlar o günlerde namaz, oruç gibi ibadetlerden hiç vazgeçmedi. Baskıya rağmen kadınlar köylerde başlarını özgürce örtebiliyorlardı. Ama kimse İnönü’yü sevmiyordu. Çünkü evlerde Kur'an var mı diye sürekli baskınlar olurdu." 
Kocaeli Karamürsel'de yaşayan 1932 doğumlu Ali Eratik'in ifadeleri de yukardaki bilgileri destekler niteliktedir:

"Devlet din işlerini çok sıkı tutuyordu. Ancak tüm baskılara rağmen halk daha samimi ve inançlarına bağlıydı. Mesela her sene hafız cemiyeti olurdu. Baskılara rağmen dinî hayat devam etti. Halk ve yöneticiler birbirinden kopuktu ama halk dinine bağlıydı. Ramazan, sünnet ve dügün gibi zamanlarda yine dinî törenler yapılır ve bu şekilde çocuklara da örnek olunurdu. Devletin yasalarla dini sıkı tutmasında batıl inanışlar ile üfürükçüler etkili olmuştur. Ama sıkı denetime rağmen halktan bilenler bilmeyenlere öğretmek suretiyle dinî hayatın devamı sağlanmıştır.”

Özellikle "kültür muhafazâkarlığı" ve tarikatlar yoluyla dinî hayatın canlılığını sürdürme konusunda direnç gösteren halkın, idari kadronun dinî alanla ilgili tüm yasaklamalarına ve kısıtlamalarına rağmen dinî geleneklerini yaşatma konusunda başarılı olduğu görülse de (Mardin, 2010:159-160, Meriç, 1996:28, Turhan, 1969:112), bu dönemdeki dinî hayatın her türlü sosyal ve siyasi tefekkür programından uzak olduğu için bilimsel ve yüksek seviyede fikri bir tabana oturmadığı söylenebilir. Zira bu dönemde halkın algıladığ1 dinî anlayış, ezan ve ibadetlerin yüzyıllardan beri alışageldiği biçimde icra etmek, dinin temel kitabını kendi orjinal dilinde öğrenip öğretmek gibi yalnızca pratik alana yönelik taleplerden ibarettir. 1950’lere kadar hiçbir resmi ve meşru eğitim ve öğretim müessesesine sahip olmayan ve yalnızca Osmanlı medreselerinin zamanının gereklerine göre yetişmese de İslami bilgisi yine de güçlü son ürünlerince yönlendirilen “halk İslamı”nın, çiftçi, köylü, küçük esnaf ve biraz okumuş yazmış kesimden oluşan bir sosyal tabana dayandığı söylenebilir. Halk arasındaki dinî yaşayışın bilimsel ve güçlü bir entelektüel tabana oturmamış olması, mutaasıp bazı yapılanmalara yol açtığı gibi zaman zaman da değişen dünyaya kapalı bazı mistik yapılanmalarının ortaya çıkmasını da beraberinde getirmiştir. Gerçi o döneme hakim olan bu dinî anlayışın, 1950'lerde rejimin yönelimlerini değiştiren bir güce sahip olduğu bilinse de (Ocak, 1989:80), büyük oranda heterodoks inanışlarla örülü olduğu gerçeğini değiştirmemektedir (Barutçu, 1977:413).

Çalışmaya konu olan dönemde yaşanan dinî hayatın, bireysel ve toplumsal görünümler açısından belli başlı dindarlık tiplerini ön plana çıkardığı görülmektedir. Herşeyden önce halkın \%80'inin köylerde yaşadığı dönemin Türkiye'sinde, bütün dinamikleriyle geleneksel bir halk dindarlığının yaşandığı söylenebilir. Özellikle Cumhuriyetin ilk yıllarından bu yana geleneksel yapıya eşlik eden muhafazâkar tutumun ise politik tutumun etkisiyle savunmacı tepkisel bir refleks haline dönüştüğü muhakkaktır (Akkaş, 2003:245-253, Akkaş, 2001:30-31, Okutan, 2013:128, Y1ldırmaz, 1986:111-130, 
Yıldız ve Çelik, 2012:283,). Geleneğine bağlı olan Türk toplumunun, geçmişin reddedilmesi ve pozitivizm ekseninde yeniden dönüştürülmesi projesiyle devletle arasının açıldığı ve neticede kültürel güdülenme yoluyla oluşan direnmenin, uç noktalara taşındığı görülmektedir. Bununla birlikte dinî anlayış ve yaşayış biçimiyle gelişmenin önünde potansiyel bir tehlike olarak görülen halkın, devlet eliyle ötekileştirilmesi (Hizmetli, 2003:402, Sakal, 2008:25), pek çok konuda olduğu gibi dinî yaşayışta da birtakım aşırılıkları beslemiştir (Kalyoncu, 2006:48-55). Gerçi geleneksel halk dindarlığında şekilciliğin, taklitçiliğin, ritüalizmin ve tasavvufi unsurların ön plana çıktığı bilinse de (Ergil, 1986:112-116, Günay, 1999b:263, Hoffer, 2011:49) yine de kendi içinde değişimi ve gelişimi öngören bu yaşayışın, politik tutumun etkisiyle tutucu bir hal aldığı ve neticede toplumda barındırılmaması gereken değerlere körü körüne bağlanan dogmatik ve fanatik dindar tiplerinin ortaya çıkmasına zemin hazırladığı söylenebilir.

Özellikle dinî alandaki baskıları, kimliklerine yöneltilmiş bir tehdit olarak algılayan bir kesimin, kendi içine kapanarak her türlü değişime tavır almalarında din ve kültür alanındaki politikaların önemli derecede etkili olduğu şüphesizdir. Nitekim halkın büyük çoğunluğu, modernizmi bask1 ve şiddetle özdeşleştirerek rejimle çatışmalı bir pozisyonun içine girmiş ve resmi ideolojinin söylem ve uygulamalarına kendilerini büyük oranda kapatmıştır. Okullardaki öğretim programlarının manevi eğitimden mahrum olması nedeniyle sadece kız çocuklarının değil erkek çocuklarının bile okutulmak istenmediği, bu nedenle de gerekirse zor kullanılarak okullara kaydedildiği, mülakatlar esnasından dönemin canlı şahitleri tarafından dile getirilmiştir. Bu dönemde okullaşma oranındaki artışa rağmen öğrenci oranında azalmanın görülmesi, bu durumla izah edilebilir (Sakaoğlu, 1992:88-89, Turhan, 1969:145-147, Yiğit, 1992:62). Böylesi bir tavır alış, aslında değişimin uzun vadedeki olumlu gelişmelerini gölgelediği gibi sorgulamaksızın, koruyucu bir tepkiyle geleneklere körü körüne bağlanmanın da yolunu açmıştır. Anlaşılan o ki, geleneksel toplumsal kalıpların zayıflatılmasına yönelik politik tutum ve buna bağlı olarak yaşanan zorunlu kültürel değişim, savunma psikolojisi ile, dinî şuurda bir yoğunlaşmayı da beraberinde getirmiş, bu da, İ́slam dünyasının değişime karşı genel tepkisel ortamında, kendini şekilci, normatif, katı ve yüzeysel nasçı (kitabi) yorumlara, yahut çoğu zaman öfkeli siyasi ve ideolojik ifade ve eylemlere zemin hazırlamıştır (Günay, 1999a:116). Bu duruma etki tepki noktasında bir açıklama getiren Peyami Safa’ya göre:

"Muhafazası şart gelenekleri yok etmeye varan inkılap hareketleri, en ileri cemiyetlerde bile geçmişe hasret ve irtica temayüllerini kuvvetlendirir. Her aksiyonun, şiddet nispetinde bir reaksiyon 
uyandırması, bütün varlık şemalarında muteber bir kanundur. Ölçüsüz bir muhafazâkarlık olan irtica aynı nispette ölçüsüz inkılap hareketlerinin cevabıdır” (Safa, 2011:173, Turhan, 1969:322-384).

Başgil'in “fikir ve kanaat, ıslak keçeye benzer, tepildikçe sıklaşır ve sertleşir” (Başgil, 2012:112) sözünü de bu çerçevede değerlendirmek mümkündür.

Üzerinde durulan dönemde göze çarpan diğer bir dindarlık tipi de dini, Allah'la kul arasındaki ilişkiye indirgeyen ve ona sadece vicdanlarda yaşam hakkı tanıyan laik dindarlık tipidir. Cumhuriyetle birlikte ivme kazanan değişim rüzgârının özellikle şehirlerde ve kısmi olarak da köylerde bazı kesimleri etkisi altına aldığ 1 ve bu etkiyle vicdani bir mesele haline getirilen dinin, Osmanlı'nın din ve devlet bileşeni örneğindeki yerinin ortadan kaldırılmasına yönelik bir tavrı benimsettiği görülmektedir. Özellikle yönetici kesim ve aydınlar arasında benimsenen bu tavrın sosyal yaşamda önceliğini arka plana attığı dini, pratiklerden ve sosyal hayattaki etkisinden yoksun bir bağ haline getirdiği söylenebilir. Çünkü humanist bir çizgisi olan bu anlayışa göre dindar olmak için şekli ibadetlerden çok, kalp temizliği ve evrensel ahlaki ilkelerin içselleştirilmesi yeterlidir.

Toplumu modernleştirme çabalarıyla birlikte, mevcut geleneksel kültür yanında oluşan “karşı kültür”ün, yerleşik değer ve davranış biçimlerine karşıt, değer, inanç ve davranış biçimlerini yaygınlaştırması kaçınılmazdır (Ergil, 1986:1389). Ancak bu dönemde din karşıtlığg şeklinde algınan laik düşüncenin kendisi dışında başka hiç bir düşünceye yaşam hakkı tanımayan ve gerekirse farklı düşüncelere karşı her türlü yasal tedbiri gerekli gören bir anlayışı öngörmesi, bu dönemde dogmatik zihin yapısına sahip laik dindarlık tipinin varlığını da düşündürmektedir. Devlete itaati neredeyse kutsal gören bir gelenekten gelen Türk toplumunun, devletin uygun gördüğü bir dinî anlayışı benimseme noktasında duyarsız kalacağını düşünmek zordur. Nitekim kurtuluş mücadelesinde zafer kazanıp millete bağımsızlığını kazandırarak onurunu yücelten yönetici kadronun, dinî anlayış noktasında da en isabetli tercihi yapacağını düşünen bir kesime bu gün bile rastlamak mümkündür. $\mathrm{Bu}$ kesimin bu gün olduğu gibi o gün de dinin ibadet ve etki boyutuna yöneldiklerinde kendilerini rejime ihanet ediyormuş gibi hissetmeleri ise kuvvetle muhtemeldir.

Yukarıda bahsedilen dindarlık tiplerinin zorunlu kültürel değişime paralel olarak büyük oranda herodian ve zealot ${ }^{3}$ tepkinin ön plana çıkardığı tipler olduğu görülmektedir. Ancak Peyami Sefa'nın “Doğu ve Batı sentezi” olarak özetlediği yaklaşımın (Durna, 2009:44,

\footnotetext{
${ }^{3}$ Herodian, bilinmeyenin tehlikesinden korunmak için en etkili yolun karşı tarafın sırrını keşfetmekte yattığı prensibine göre hareket eden ve kendisinden daha hünerli, daha iyi silahlanmış olan birisiyle karşılaştı̆̆ında geleneksel savaş tekniğini unutarak düşmanın taktik ve silahıyla savaşmayı ögrenen insandır. Zealot, bilinmeyenden teklifsizce kaçan, yabancı birisi
} 
Safa, 2013:188) yani geleneksel ve modern anlayışın senteziyle şekillenen bir dindarlık tipinin varlığından da söz etmek gerekir. Özellikle şehirlerde yaşayan bu kesimin bir yandan liberal, demokrat ve laik bir anlayışı benimserken diğer yandan sahip olduğu değerleri korumaya ve gelecek nesillere aktarmaya yönelik bir tutum içerisinde olduğu görülmektedir. Zira bu kesimin, İmam Hatip okulları açılır açılmaz çocuklarını bu okullara kaydetmesi, bir yandan sahip olduğu değerlere sıkı sıkıya bağlı kalıp bir yandan da henüz oturmamış olsa da uzun vadede modernizmin olumlu getirilerini kabul ederek rejimle bir uzlaşı gayreti içerisine girdiklerini göstermektedir. Zaten dönemin laik politikalarıyla sekülerleştirilmeye çalışılan dinî hayatın, İslam'ın ve modernizmin karmaşık ilişkilerinden doğan “melez desenleri” ortaya çıkarmayacağını düşünmek zordur (Göle, 2011:17). Bu “melez desenler” içerisinde Günay’ın “tranziyonel dindarlık” adını verdiği ve günlük hayatında bazı konularda din işleriyle dünya işlerini birbirinden ayıran, bazı konularda ise, dinî referans alarak dinden kaynaklanan tutum ve davranışlara yer veren bir kesimin var olduğunu söylemek de mümkündür (Günay, 1999b:264).

Halk kesiminin kutsala olan inanç noktasında herhangi bir problemi olmadığı, yani dine atfettikleri anlam çerçevesinde inandıkları varlıkla tecrübi bir ilişki içerisinde bulundukları muhakkaktır. Ancak Batılılaşmanın beraberinde getirdiği seküler yaşam tarzının resmi ideoloji tarafından dayatılması, belli kesimler üzerinde, dinin davranış ve etki boyutunun ortadan kalkması yönündeki bir anlayışı geliştirerek, inancı sadece Allah kul arasında yaşanan tecrübi bir ilişki haline dönüştürmüştür. Dinin sosyal hayattaki etkisinin bertaraf edilmesi yönündeki bu politikaların, özellikle iletişim ve sosyalleşme noktasında büyük işlev gören camilerdeki toplu ibadetleri neredeyse yok denecek kadar azalttığ1 bilinmektedir. $\mathrm{Bu}$ dönemde namaz, oruç gibi evlerde yapılan ibadetlere toplu olmadığ1 müddetçe herhangi bir müdahalenin olmadığı bilinse de, bu ibadetlerin çoğunlukla orta yaş üzeri bireyler tarafından yerine getirildiği söylenebilir. Çünkü büyük bir bölümü köylerde yaşayan halkın uzun yıllardan beri resmi din eğitiminden mahrum olması, dinin pratik yönlerini uygulayan bireylerin nazari bilgi bakımından zayıf kalması, bu noktada aileden alınan eğitimin ise yetersiz olması gibi faktörlerin, özellikle bazı gelişim dönemleri açısından zaafiyet doğurduğu düşünülmektedir. Her ne kadar şehirlerde yaşayan okullu gençlerin Kutsalla olan ilişkilerinin çok zayıfladığı, dönemin şahitleri tarafindan dile getirilse de, yaşanan tüm zaafiyete rağmen dinin inanç ve tecrübi boyutunun özellikle orta yaş ve üzeri

karşısına son model silahlarla çıkıp, üstün taktiklerle savaşa giriştiğinde ve bu karşılaşmada durumu kötüye gittiğinde, kendi geleneksel savaş tekniğini titiz bir şekilde uygulayan insandır. (Toynbee, 1991:168-186.) 
için ekonomik yoksunlukları telafi etmede ve tüm olumsuzluklar karşısında hayatı yaşanılabilir kılmakta telafi mekanizması olarak işlev gördüğü söylenebilir.

Dinin bilgi boyutunun resmi ideoloji tarafından ihmal edilmesi sonucu heterodoks inanışların halk arasında fazlaca yaygınlaştığı muhakkaktır. Ancak dönemin ikinci yarısında bu noktadaki politikaların yanlış olduğu fark edilerek bazı dinî kurumların açılması ve okullarda resmi din eğitimi verilmesi gündeme gelmişstir. Ancak bu gelişmeler olana kadar gayrı resmi yollardan elde edilen bilgiler, gündelik hayatta temel ibadetler için yeterli gibi görünse de, dinin entelektüel boyutunun inkişafı adına yetersiz kalmıştır. $\mathrm{Bu}$ da dinin geliştirici fonksiyonlarının bu dönemde çok da işlevsel olamadığını düşündürmektedir. Gerçi bu dönemde hayata anlam atfettme noktasında dinin psikolojik direnci artırıcı etkisi hissedilse de, genel olarak savunmacı bir refleks içerisinde olan halk için, dinin büyük oranda telafi işlevi gördüğü söylenebilir. Dönemin tepkisel ortamı içerisinde bireylerin sahip oldukları değerleri kaybetme endişesiyle inançlara sıkı sıkıya bağlanmaları ise bu alanda zayıf da olsa bir farkındalık oluşturduğu kadar muhafazakâr tutumun açık bir örneğini oluşturmuştur.

\section{DÖNEMIN DİNDARLIĞININ GÜNÜMÜZ DINDARLIĞINA YANSIMALARI}

Çalışmaya konu olan dönemde dinî alanı da önemli ölçüde etkisi altına alan politik atmosferin genel olarak "modern" ve "geleneksel" arasındaki gerilimlere sahne olduğu görülmektedir. Tanzimat dönemi "Batılılaşma" çabalarıyla başlayan ve Cumhuriyet dönemi modernleşme projesiyle birlikte daha derinden hissedilen bu gerilim, kendisini "İslamc1Batıcı", "gerici-ilerici” gibi ikilikler üzerinden göstermekte ve pekçok çatışmayı da beraberinde getirmektedir. Örneğin "bilimsel bilgi/ dinî bilgi”, "kamusal alan/ özel alan", "laiklik/ demokrasi” gibi döneme damgasını vuran çatışmaların genel olarak "modern" ve "geleneksel” arasındaki gerilimin bir uzantısı olarak yaşandığı görülmektedir (Akşit ve arkadaşları, 2012:157-158).

Cumhuriyet tarihinin önemli bir kesiti olan ve bir nevi rejimin çocukluk dönemi olarak kabul edilebilecek 1938-1950 yılları arasında yaşanılanların üzerinden çok uzun zaman geçmesine rağmen, özellikle dinî açıdan bakıldığında günümüzle önemli benzerlikler arz ettiği söylenebilir. Her ne kadar dine olan bakış açısı bugün daha esnek bir hal almışsa da, o dönemde yaşanan gerilimlerin bugün hala mevcut olduğu ve dinî hayatın da tıpkı o dönemde olduğu gibi bu gerilimler ekseninde şekillendiği bir gerçektir. Bu noktada dikkat çeken en önemli şey belki de o dönemde insanların neredeyse kesin çizgilerle "laik" ve "dindar" diye ikiye ayrılmaları iken, bugün bu iki kavramın kol kola girmesiyle "laik dindar" tipine fazlaca 
rastlanır olmasıdır. Çünkü modernleşmeyle birlikte başlayan süreçte yaşanan çelişkiler, gündelik yaşam pratiklerinde, gerilimlerdeki kutupların iç içe geçmesiyle melez çözümler bulunarak yaşanmaktadır. Böylesi bir melezleşmenin elbetteki laikliğe atfedilen anlamla yakın ilişkisi vardır. Zira o gün din karşıtlığı şeklinde anlaşılan laiklik bugün din ve vicdan hürriyetinin bir teminatı olarak algılanmaktadır (Turam, 2007:138-140).

Günümüz toplumunda sekülerizme bağlı olarak dindarlığın anlam ve içerik yönünden biçim değiştirdiği, siyasi ve ekonomik kaygıların daha fazla ön plana çıktığı görülmektedir. Yani Kutsal olanın, tam da dünyevi olanın ortasında bir yerlere yerleştirilmeye çalışıldığı bu süreçte, dinî hayat ve dindarlık algısı da buna göre şekillenmektedir (Turam, 2007:138-140). Yavuz'a göre kendisine has farklı bir İslami algısı olan bu nedenle de "Türkiye İslamı" olarak nitelendirilen bu yaşayışta, İslam'ın genel olarak insanların ahlaki davranışları üzerinde fazla etkili olmadığı, bu nedenle de inanç ve ibadet arasında derin uçurumların bulunduğu görülmektedir (Yavuz, 2004, 227). Günlük hayatın hemen her alanında kendisini hissettiren bu durum, Çarkoğlu ve Toprak'ın araştırmasına da yansımıştır. Nitekim bu araştırma sonucuna göre \%97'si Müslüman olan toplumun sadece \%46'sı beş vakit namaz k1lmaktadır (Çarkoğlu, 2000:40-45).

Arslan'ın, halkın büyük bir kısmının eski kültürü ve dinî inanışları da bünyesinde barındıran sistemsiz inanç ve uygulamaların hakim olduğu popüler bir dinî hayatı sürdürdügünü iddia ettiği yaşantıya, bazı cemaat yapılanmalarındaki taassubunun da eklenmiş olması, bu konudaki dejenerezasyona ayrı bir boyut kazandırmaktadır (Arslan, 2003:101). Bu durumun 40’lı yıllardaki baskıcı politikaların bir sonucu olduğunu düşünmek yanlış olmasa gerektir. Zira bu dönemde devlete karşı oluşan tepkilerin bir kısmı sonraki yıllarda kendini devlete güvensizlik, bir kısmı da siyasi otoriteyi dinsizlikle suçlama şeklinde kendini göstermiştir (Çetin, 2012, 190). Devlete karş1 güvensizlik ve şüpheci yaklaşımın bugüne yansımaları içerisinde en dikkat çekenlerden birisi bazı cemaat yapılanmalarının kendilerini güvende hissedebilme adına hiyerarşik bir örgütlenmeyle güç olma mücadelesinin içine girmiş olmalarıdır. "İmanı kurtarma” adına dinî bir hareket olarak ortaya çıkan bu yapıların o dönemde yaşadıkları güvensizliğin meşru bir dayanağı varken ve bugün bu dayanaktan yoksun olmalarına rağmen aynı şüpheciliği ve güvensizliği göstermeleri, muhafazâkar tepki zihniyetinin tipik ifadesi olmakla birlikte değişime paralel bir gelişme göstermeyişlerinin de kanitidir.

Çalışmaya konu olan dönemde zorunlu kültürel değişime bağlı olarak din, dil ve tarih gibi alanlarda yaşanan değer kaybının bireyler tarafından sindirilememiş ve benimsenememiş 
olmasının günümüze yukarda bahsedilen olumsuzluklar şeklinde yansıdığı açıktır. Zira geçmişte yaşanan sosyal travmalar "seçilmiş travmalar" halini almışsa yani yaşanan acı ve kaybın yası tutulamamışsa, yaşanacak olumsuzlukların bilinç ve bilinçdışı paylaşımlarla gelecek nesillere aktarıldığı ve böylece yeni nesillerin kimliklerinin bir parçası haline geldiği bilinmektedir. Hâlbuki travmanın çözülebilmesi için yaşanan acı ve kaybın iyi ve kötü, olumlu ve olumsuz yanlarının değerlendirilerek sonucun benimsenmesi, bünyeye kazandırılması ve böylece kişiliğin ve kimliğin güçlenerek ve zenginleşerek varlığını sürdürmesi gerekir (Çevik, 2010:128, Tarhan, 2010:72-73).

Gelinen noktada geçmişte yaşanan değişim ve dönüşümün duygusal onayla olmaması ve dönemin baskıcı politikalarının da etkisiyle cemaatler vasıtasıyla yeraltına çekilen İslam'ın, modern hayattan yani şehirlerden taşra kasabalarına ve köylere itilmesiyle kapalı bir hayat yaşamaya mahkum edilmesi, Türkiye Müslümanlığının da uzun bir süre köylü ve taşralı kalmasına sebep olmuş, "arabesk İslam” denilen bir görüntünün ortaya çıkmasına yol açmıştır (Ocak, 1996:135-136). Bu görüntünün de Altan'ın tasvirini yaptığı “kent dindarlığı”’ndan uzak olduğu muhakkaktır. Zira "kent dindarlığı; eğitimli, refah düzeyi yüksek, donanımlı, yaşam bilgisi gelişmiş, kendisine değerler katmış, kendisini eğitip zenginleştirmiş insanların âlemidir.” (Altan, 2010:76).

Günümüz dindarlığı açısından dikkat çeken diğer bir görüntü de Ocak’ın “Kemalist Müslümanlık” dediği yaşam tarzıdır. İslam’a yalnızca kişilerin vicdanında hayat hakkı tanıyan ve ibadetleri de okumamış "cahil” halka bırakan bir çeşit kült Müslümanlığı, Batıcı aydınlardan, bürokrasiden, eğitim kurumlarından ve basından başlamak üzere yavaş yavaş aşağılara doğru inmeye başlamıştır. Bu Müslümanlık anlayışının bugün halk arasında da küçüksenmeyecek bir taraftar zümresine sahip olduğunu görmek zor değildir. İnancı sadece Allah'la kul arasındaki ilişkiye indirgeyen bu kesimin kalp temizliğini dindar olmak için yeterli gördükleri ve ahlak ilkelerine yaptıkları vurguyla humanist laik bir dindarlık anlayışını benimsedikleri söylenebilir. Ancak günümüzün humanist laik dindarlarını döneminkilerden ayıran belki de en önemli özellik, bu insanların kendilerini seküler olarak tanımlayıp dinî yaşamlarını özel alanlarıyla sınırlandırırken, farklı pratiklerle oldukça "dindar” bir yaşam sürdüklerini sıkça dile getiriyor olmalarıdır (Ocak, 1996:133-134). Gerçek şu ki, dinî inançlarını günlük hayatlarına yansıtmamaya gayret eden bu insanlar, dinin hiç yer almadığı bir yaşam tarzına da sıcak bakmayarak bir nevi algı yanılması içine düşmekte ve bu şekilde inanç ve davranış arasındaki bütünlüklerini kaybetmektedirler (Karaca, 2007:270-280, Kuşat, 2012:157-160). Çünkü ibadet veya dinî davranış, dinî hayatı besleyen önemli güç 
kaynaklarıdır. Bu kaynaktan yoksun olunması halinde yaşanan bilişsel çelişkiyi bastırmak için zamanla mevcut durumu meşrulaştırma ve aklileştirme gibi bir savunma gelişeceğinden, bireyin aslında yaşamadığı halde kendisini dinî bir hayat yaşıyormuş gibi hissetmesine yol açabilmektedir (Karaca, 2011:133-140, Yapıcı, 2007:27-28).

Son dönemlerde dinî hayatın toplumsal görünümleri içerisinde oldukça sıradışı kabul edilebilecek yeni dinsel hareketlerin varlığından da söz etmek gerekir. Zira modern Türkiye'de özellikle son dönemlerde yaşanan hızlı değişimler, dünyaya aşırı yönelim, aşırı rasyonalizm, pozitivizm ve materyalizm, bir otorite ve inanç boşluğu olgusunu da beraberinde getirmiş, böylece ortaya çıkan sosyal anomi ortamında aşırı laikleşme sonucunda kenara itilen geleneksel inançlar ve dinler, bu manevi ihtiyaçlara cevap veremeyince doğan boşluk, yeni dinsel hareketler tarafından doldurulmak istenmiştir. Bu bağlamda Zen, Yoga, İlahi Işık misyonu, Allah'ın çocukları gibi hareketler örnek olarak gösterilebilir (Okumuş, 2010:173).

Dinsellik görünümündeki tüm farklılıklar, insanın içinde yaşadığı kültürel ortamda meydana gelen değişimlerin özellikle sanayi alanında ortaya çıkan gelişmelerin, insan hayatını ve buna bağlı olarak dinsel yaşamını belirleyici bir etkiye sahip olduğunu göstermektedir (Yapıc1, 2007:24). Bugünün insanı, kendini birey olarak yaşamaya zorlayan şartlar tarafından kuşatıldığı için dinini de artık toplumsal boyutundan daha çok bireysel boyutuyla yaşamak zorundadır. Dünün geleneksel toplumsal dindarlığından bugünün bireysel dindarlığına zorunlu geçiş yapan günümüz insanının geleneksel dinsel yaşayıştan uzaklaşmış olsa da tamamen inançsız bir yaşayışı benimsediğini iddia etmek mümkün değildir. Çünkü toplumsal seviyedeki sekülerleşmenin mutlaka bireysel bilinç seviyesinde de gerçekleşmesi beklenemez. Nitekim bazı dinî kurumlar toplumda güç ve etkinliğini yitirmiş olsa da hem eski hem de yeni dinî yaklaşımlar bazen yeni kurumsal şekillere bazen de aşırı bir dinî ifadeye dönüşerek fertlerin hayatındaki yerini korumuştur (Hökelekli, 2001:12). Bu durumda inanan ve inandığı değerleri hayata geçirmek isteyen bireyin, kendi başına da olsa sahip olduğu inanca özgün bir yapı kazandırarak ve bu inancının gereklerini yerine getirerek iç güdümlü bir dindarlığı yaşamasının mümkün olduğu söylenebilir (Ok, 2012:129-130). Zira gücünü kendi iç donanımlarında alan günümüz insanının, toplumda sorgulanmadan alınan değerleri gözden geçirerek yeni hedeflere yönelmesi ve iç güdümlü bir dindarlık yönelimine sahip olması da söz konusudur (Günay, 2001:25, Kayıklık, 2006:156-169).

Halkın küçük bir kesimi de olsa inançlarını içselleştirerek bünyesine mal eden bireylerin dine ait farkındalıklarının gelişmesinde tarihsel süreçler kadar benimsenen politik anlayışın dine yaklaşımının da etkili olduğu bir gerçektir. Zira 40'11 yılların katı devletçi 
politikalarının aksine günümüzün liberal demokrasi anlayışı çerçevesinde din ve vicdan özgürlüğüne önem verilmesi ve gerek eğitim kurumları gerekse Diyanet vasıtasıyla dinî hayatın gelişmesi için yapılan faaliyetlerin desteklenmesi, bu konuda olumlu gelişmelerin zeminini hazırlamaktadır. Ancak dinî hayatla ilgili yaşanan gelişmelere rağmen bilinçli dindarlık düzeyinin istenen noktada olmadığı ve beklenen toplumsal dönüşümün sağlanamadığı muhakkaktır. Toplumun büyük bir kesiminin, yaşadığı popüler dindarlıkla, heterodoks inanışlara meyilli, kendisini sürekli üreten geleneksel bir dinî yaşantıyı sürdürdükleri gözlenmektedir. Bu yaşantıda Kutsalın çoğu zaman akıllara geldiğinde hatırlanan veya beklentilerinin gerçekleşmesi şartıyla kendisine yönelinen hatta gerektiğinde mevcut kazanımları meşrulaştıran bir varlık olarak algılanması, dindarlık yönelimlerinin dış güdümlü olduğuna işaret etmektedir (Allport and Ross, 1967:434-441, Pargament, 2005:285). Faydacı bir anlayış üzerine bina edilen bu yönelimin önyargıyı beslemesi ise, toplumdaki hoşgörü düzeyini olumsuz yönde etkileyerek insanların manevi yönden birlik ve beraberlik içinde bulunmalarını engellemekte ve birbirlerini ötekileştirmeleri gibi bir sonucu doğurmaktadır. Bu olumsuz durumun, dine atfedilen anlamla yakından ilişkisi vardır. Zira geleneksel dindarlar için din, atalardan görüldüğü şekliyle benimsenip bağlanılan ve şekli birtakım ibadetlerin yerine getirilmesiyle huzura ulaşılacağı düşünülen bir değerler sistemi olarak algılandığından, muhakeme ve idrakten büyük ölçüde yoksundur. Kaderci yönü ağır basan böyle bir dinî anlayışta, iki günü birbirine eşit olmasın diye kendini sürekli geliştiren, kendisi için istediğini başkaları için de istemesini bilen ve bütün yaratılanları yaratandan ötürü seven bir dindarlık bilincinin gelişmesini beklemek zordur. Günlük hayatta kendisini dindar olarak tanımlayan kişilerin Kutsalla ve diğer varlıklarla girdiği ilişkinin dışa yansıyan görüntüleri bu durumu doğrulamaktadır. Nitekim bu insanların özellikle insan-Tanrı, insaninsan ve insan-çevre ilişkileri noktasında birtakım olumsuz tutum ve davranışlar içerisinde bulunmaları çok sık rastlanılan durumlar arasındadır. Günlük hayatta sıkça karşılaşılan bu olumsuzluklar, dinin, geleneksel dindarların dünyevi hayatla ilgili tutumları üzerinde gereken etkiyi bırakmamasıyla izah edilebilir. Çünkü sağlıklı bir dindarlık anlayışının gelişmesi için bireyin Tanrıyla olan ilişkisinin diğer ilişkileri üzerinde etki bırakması ve bu etkinin hayatının her alanına yansıması şarttır (Stark and Glock, 1974:16, Pargament, 2005:304, Vergote, 1999:30). Zira din, Kutsalla girilen tecrübi ilişkinin gereği olarak hayatın tüm boyutlarını dışarda hiçbirşey bırakmamacasına kucaklayan bir yaşam tarzı, daha açık bir ifadeyle "hayatın ta kendisi”dir (Subaşı, 1995:253-258). Tarihin her döneminde dinî alandaki politikaların dindarlık profillerini önemli ölçüde etkilediği bilindiğinden sağlıklı bir dinî 
gelişim için dinî alanın hertürlü politik baskıdan mümkün olduğunca uzak olması önemlidir (Mahçupyan, 2014:20).

Yapılan tüm değerlendirmeler çerçevesinde günümüzle dönemin dindarlık tipleri karşılaştırıldığında yine iki temel görüntünün ağırlıklı olarak dikkat çektiği söylenebilir. Geleneksel-muhafazâkar dindarlık ile humanist-laik dindarlık, kendi çatısı altında çok çeşitli görünümleri barındırmasına rağmen birtakım farklılıklarıyla bu döneme de damgasını vurmuş gibidir. Dönemin geleneksel halk dindarlığının bugün popüler dindarlık adı altında devam ettiği, ancak yaşanan gelişmelere paralel bir çeşitlilik arz ettiği görülmektedir. Özellikle dönemin meyveleri olarak ortaya çıkan cemaatlerin tamamı olmasa da önemli bir kısmı dinî bir çizgiden seküler bir çizgiye doğru kaymasıyla popüler dindarlığın cemaat taassubuyla birleşmesi gibi bir sonucu doğurduğu söylenebilir.

Dinin hem 40’lı y1llarda hem de günümüzde insan hayatında ne kadar etkili olduğu tartışmalı bir konudur. Sadece dün ve bu gün değil tarihin her döneminde dinin araçsal ve amaçsal yaklaşımlara konu olduğu bilinen bir gerçektir. Örneğin 40’lı yıllarda dinin hem mevcudu koruma hem de mevcudu ortadan kaldırma konusunda bir enstrüman gibi kullanıldığı görülmektedir. Nitekim dün birileri için hayatın merkezinde motive edici ve sosyal kimlik sağlayıcı bir güç, birileri için hayatta karşılaşılan zorlukların üstesinden gelme noktasında kullanılan bir telafi mekanizması, birileri için de gelişmenin önünde mutlaka bertaraf edilmesi gereken tehlike olarak algılan dinin, bugün de etki noktasında dünden farklı durumda olmadığı ve yine hayatın tamamını kapsayan bir özelliğe kavuşamadığı söylenebilir. Bu durumda şöyle bir sonuca ulaşmak mümkündür: Dinî hayat her ne kadar içinde yaşanılan ortamın etkisiyle şekillenen bir özelliğe sahip olsa da, kendine özgü dinamikleriyle bağımsız bir gelişim seyri izleyen ve insanların niyetlerine ve onu ciddiye alış düzeyine paralel bir etkiye sahip olan özgün bir yaşantıdır.

\section{SONUÇ}

Yapılan değerlendirmeler sonucunda çalışmaya konu olan döneme hakim olan politik atmosferin dinî hayatı büyük oranda etkileyecek birtakım özellikler arz ettiği görülmüştür. Nitekim özellikle kültürel alanda yeni bir anlayışın hakim kılınmaya çalışıldığı bu dönemde, 2. Dünya Savaşının da etkisiyle yaşanan ağır ekonomik krizin, bireylerin yaşamına genel olarak olumsuz yansıdığı, Halkevleri ve Köy enstitüleri gibi yaygın ve örgün eğitim kurumlarıyla rejimin resmi ideolojisinin halk tabanına yayılmaya çalışıldığı ve bu suretle 
halkın benimsediği geleneksel değerlerin yerine yenilerinin ikame edilerek köklü bir toplumsal dönüşümün sağlanmak istendiği görülmektedir. 2. Dünya Savaşı sonrasında dış dünyada oluşan bloklaşmanın ABD ile Sovyet Rusya arasında soğuk savaşa yol açmasının Türkiye'de demokratikleşme rüzgarlarının esmesine ve dolayısıyla dinî hayatın rahatlamasına yol açarak yaşanan gelişmelere yön verdiği söylenebilir.

Mevcut geleneksel yapının muhafazakâr bir tutumla birleşmesinin dönemin dinî gelişim sürecine olumsuz yansıyarak bu alandaki gelişmelerin önünü tıkadığı anlaşılmaktadır. Nitekim dinî alandaki yasaklayıcı ve baskıcı tutumun korumacı ve savunmacı bir refleksi doğurduğu ve bu refleksle dine yönelen bireylerin mevcudu, iyi-kötü ayrımı yapmadan koruma gayreti içine girdikleri görülmüştür.

Tüm yaşananların farklı dindarlık profillerinin ortaya çıkmasına yol açtığı ve özellikle resmi ideolojinin empoze ettiği dinî anlayışı benimseyen bireylerin bu anlayışla geleneksel halk kesiminden dindarlık noktasında ayrıldığı söylenebilir. Bunun neticesinde yapılan tüm tespitler doğrultusunda geleneksel halk dindarlığı ve humanist laik dindarlık olmak üzere iki farklık dindarlık tipolojisinin, kendi içinde barındırdıkları tüm anlayış farklılıklarıyla birlikte döneme damgasını vurduğu dikkat çekmektedir.

Dönemin dindarlığı ile günümüz dindarlığı karşılaştırıldığında yaşanan tüm gelişmelere rağmen beklenen toplumsal dönüşümün sağlanamadığı söylenebilir. Zira bu dönemde de yine ağırlıklı olarak geleneksel halk dindarlığı ve humanist laik dindarlık tipi ön plana çıkmakta, ancak çalışmaya konu olan dönemden farklı olarak özgün bir dinî anlayışın varlığını bu dönemde daha derin hissettirdiğini söylemek mümkün olmaktadır. İlgili dönemin meyveleri olarak ortaya çıkan cemaat yapılanmalarının bugün toplum nazarında büyük oranda etkili olduğu, ancak benimsedikleri geleneksel dinî anlayışla popüler dinî yaşantının birer parçası haline geldikleri, bu nedenle tamamı olmasa bile büyük bir kısmının dinî bir yapıdan çok seküler bir yapı haline dönüştüğü dikkat çekmektedir. Bu durum, günümüz insanının dini doğru anlaması için pek çok imkâna sahip olmasına rağmen akli düşünme yeteneğini yeterince aktif hale getirmemesiyle izah edilebilir.

Sonuç olarak dinî hayat, içinde bulunduğu ortamdan etkilenmekle birlikte, kendine özgü dinamikleriyle özgün bir gelişim seyri izleyen ve bireylerin niyetlerine ve bilinç düzeylerine göre fonksiyonel olan özgün bir yaşantı olma özelliğini devam ettirmektedir. 


\section{KAYNAKÇA}

Akkaş, Hasan Hüseyin, (2001). “Türk Modernleşme Tarihinde Muhafazâkar Siyasi Düşünce”, Afyon Kocatepe Üniversitesi, Sosyal Bilimler Dergisi, 3(2), 28-39.

Akkaş (2003). "Muhafazâkar Siyasi Düşünce Kavramı Üzerine”, Afyon Kocatepe Üniversitesi Sosyal Bilimler Dergisi, 5(1), 241-254.

Akşit, Bahattin ve Arkadaşları (2012). Türkiye'de Dindarlık, Sosyal Gerilimler Ekseninde İnanç ve Yaşam Biçimleri. İstanbul: İletişim Yayınları.

Alkan, Türker (1989). Siyasal Bilinç ve Toplumsal Değişim, Siyasal Bilincin Gelişmesinde Ailenin, Okulun ve Toplumsal Sinıfların Etkisi. Ankara: Gündoğan Basın Yayın Dağıtım.

Allport, Gordon W. and Ross, J. Michael (1967). "Personal Religious Orientation and Prejudice”, Journal of Personality and Social Psychology, 5(4), 432-443.

Altan, Mehmet (2010). Kent Dindarlı̆̆ İ İstanbul: Timaş Yayınları.

Arar, İsmail (1969). Atatürk’ün İzmit Basın Toplantısı, İstanbul: Burçak Yayınları.

Argyle, Michael - Hallahmi, Benjamin Beit (1975). The Social Psychology of Religion, London: Routletge\&Kegan Paul.

Armağan, Mustafa (2008). Yakın Tarihin Kara Delikleri, İstanbul: Timaş Yayınları.

Armağan, (2010). Türkçe Ezan ve Menderes, Bir Devrin Yazılmayan Gerçekleri, İstanbul: Timaş Yayınları.

Arslan, Mustafa (2003). "Popüler Dindarlık Ölçeğinin Geliştirilmesi: Geçerlik ve Güvenirlik Çalışması", Dinbilimleri Akademik Araştırma Dergisi, III(1), 97-116.

Arslan, (2004). Türk Popüler Dindarlı̆̆ (Çorum Örneği), İstanbul: Dem Yayınları.

Ataç, Nurullah (1957). Söz Arasında, Ankara: Dost Yayınları.

Atay, Tayfun (2011). Din Hayattan Çıkar, Antropolojik Denemeler, İstanbul: İletişim Yayınları.

Aydemir, Şevket Süreyya (1993). Íkinci Adam (1938-1950) III, İstanbul: Remzi Kitapevi.

Bahadır, Abdülkerim (2010). "Dindarlığı Etkileyen Faktörler”, Din Psikolojisi, (Ed: Hayati Hökelekli), Eskişehir: Anadolu Üniversitesi Yayınları.

Banguoğlu, Hasan Tahsin (1984). Kendimize Geleceğiz, İstanbul: Derya Dağıtım. 
Başaran, Mehmet (2003). Köy Enstitüleri, İstanbul: Cumhuriyet Kitapları.

Başgil, Ali Fuad (2009). Din ve Laiklik, İstanbul: Yağmur Yayınları.

Başgil, (2012). Yakın Maziden Hatıra Kırıntıları, İstanbul: Yağmur Yayınları.

Boratav, Korkut (1989). “İktisat Tarihi 1908-1980”, (Haz. Sina Akşin), Türkiye Tarihi 4, Çă̆daş Türkiye 1908-1980, Ankara: Cem Yayınevi.

Bulaç, Ali (2012). Modern Ulus Devlet, Bütün Eserleri-13, İstanbul: Çıra Yayınları.

Coşkun, Ali, (2005). Sosyal Değişme ve Dinî Normlar, İstanbul: Dem Yayınları.

Çağlar, Behçet Kemal (6 Ekim 1940). “Dinimiz” Ulus Gazetesi.

Çağlar, (Eylül 1942). “Bizim Mevlüt”, Yücel, Aylık Sanat ve Fikir Mecmuası, (16), 91-93.

Çarkoğlu, Ali ve Toprak, Binnaz (2000). Türkiye’de Din Toplum ve Siyaset, İstanbul: TESEV Yayınları.

Çetin, Ensar (Ocak - Haziran 2012). “Türk Halkının Aydın Din Alimi Algısı”, Toplum Bilimleri, 6(11), 189-204.

Çevik, Abdülkadir (2010). Politik Psikoloji, Ankara: Politik Yayınları.

Delay, Jean - Pichot, Pierre (1975). "Psikolojinin Tanımları, Metodları, ve Komşu Disiplinlerle İlgileri”, (Çev. Erdoğan Fırat), Ankara Üniversitesi Illahiyat Fakültesi Dergisi, XX, 323-343.

Deringil, Selim (1994). Denge Oyunu,-İkinci Dünya Savaşı’nda Türkiye’nin Dış Politikası, İstanbul: Tarih Vakfı Yurt Yayınları.

Dikici, Ali (Kasım 2008). "Millî Şef İsmet İnönü Dönemi Laiklik Uygulamaları”, Ankara Üniversitesi Türk İnılâp Tarihi Enstitüsü Atatürk Yolu Dergisi, (42), 161-192.

Durna, Tezcan (2009). Kemalist Modernleşme ve Seçkincilik, Peyami Safa ve Falih Rıfkı Atay'da Halk Inşsası, Ankara: Dipnot Yayınları.

Ekincikli, Mustafa (2008). “İkinci Dünya Savaşı’nda Türk Dış Politikası”, Süleyman Demirel Üniversitesi Fen Edebiyat Fakültesi Tarih Bölümü Atatürk İlkeleri ve Inkllap Tarihi Bölümü Uluslararası Türkiye Cumhuriyeti Sempozyumu Bildirileri 22-24 Ekim, (Haz. Murat Kılıç), Isparta.

Elbir, Bilal- Karakaş, Ömer (2007). "Cumhuriyet Dönemi Türk Kültür ve Edebiyatında Hümanizmin Etkileri”, Turkish Studies International Periodical For the Languages, Literature and History of Turkish or Turkic, 2(4), 381-392. 
Ergil, Doğu (1986). İdeoloji, "Milliyetçilik, Muhafazâkarlık, Halkçılık”, Ankara: "S” Yayınları.

Eyüboğlu, Sabahattin (1999). Köy Enstitüleri Üzerine, İstanbul: Yeni Gün Haber Ajans Basın ve Yayınc1lık.

Freud, Sigmun (2011). Kitle Psikolojisi, (Çev. Kamuran Şipal), İstanbul: Cem Yayınevi.

Feroze, Muhammed R. (1995). “Laiklikte Aşırılık ve Ilımlılık”, Türkiye’de İslam ve Laiklik, Derleme, İstanbul: İnsan Yayınları.

Gerger, Mehmet Emin (1991). Bütün Yönleriyle İnönü-Menderes Mücadelesi Ve Demirkırat Oyunu, İstanbul: Akbel Yayınları.

Goloğlu, Mahmut (1974). Milli Şef Dönemi (1939-1945), Ankara: Turhan Kitapevi.

Göka, Erol (2011). Türklerin Psikolojisi, İstanbul: Timaş Yayınları.

Göle, Nilüfer (2011). Melez Desenler, İslam ve Modernlik Üzerine, İstanbul: Metis Yayınları. Günay, Ünver (1999a). “Dinin Bireysel ve Toplumsal Boyutu”, Ankara Üniversitesi İlahiyat Fakültesi Dergisi Özel Sayl.

Günay, (1999b). Erzurum ve Çevre Köylerinde Dinî Hayat, İstanbul: Erzurum Kitaplığı.

Günay (2001). “Çağdaş Türkiye'de Din, Toplum, Kültür, Gelenek ve Değişme”, ÇÜIIFD, 1 (2), 1-38.

Hizmetli, Sabri (2003). “Demokrasi ve İnsan Hakları Bağlamında Çağdaş Türkiye'de Dinî Hayat ve Din Öğretimi Alanında Gelişmeler”, II. Din Şurası Tebliğ ve Müzakereleri, (23-27 Kasım 1998) (II), Ankara: Diyanet İşleri Başkanlığı Yayınları.

Hoffer, Eric (2011). Kesin İnançlılar, (Çev. Erkıl Günur), İstanbul: Plato Film Yayınları.

Hökelekli, Hayati (2002). “Gençlik ve Din”, Gençlik, Din ve Değerler Psikolojisi, Ankara: Ankara Okulu Yayınları.

İlhan, Atilla (1982). Hangi Batı, Ankara: Bilgi Yayınevi.

İnönü, Erdal (1996). Anılar-Düşünceler 1, İstanbul: İdea Yayınları.

Kalkanoğlu, Semih (1991). İsmet İnönü: Din ve Laiklik, İstanbul: Tekin Yayınevi.

Kalyoncu, Hamdi (2006). Liderlere Tapınma Psikolojisi, İstanbul: Marifet Yayınları.

Karaca, Faruk (2001). Psiko-Sosyal Açıdan Yabancılaşma ve Din̂̂ Hayat, İstanbul: Bil Yayınları.

Karaca, (2007). Dinî Gelişim Teorileri, İstanbul: Dem Yayınları. 
Karaca (2011). Din Psikolojisi, Trabzon: Eser Ofset Matbaacılık.

Karacoşkun, M. Doğan (2006). Dinî ve Sosyal Psikoloji Yazıları, 1 Samsun: Din ve Bilim Yayınlar1.

Karaosmanoğlu, Yakup Kadri (1940). “Hümanizmaya Doğru İlk Adım”, Ayın Tarihi, (83).

Karatepe, Şükrü (1997). Tek Parti Dönemi, İstanbul: İz Yayıncılık.

Karpat, H. Kemal (2009). Osmanlı'dan Günümüze Elitler ve Din, İstanbul: Timaş Yayınları.

Karpat, Türk Demokrasi Tarihi (2010). (Sosylal, Kültürel, Ekonomik Temeller), İstanbul: Timaş Yayınları.

Kayıklık, Hasan (2006). "Değişen Dünyada Birey, Din ve Dindarlık”, Dindarlığın SosyoPsikolojisi, (Ed. Ünver Günay, Celaleddin Çelik), Adana: Karahan Yayınları.

Kirby, Fay (2010). Türkiye’de Köy Enstitüleri, (Çev. Niyazi Berkes), İstanbul: Tarihçi Kitapevi.

Kocabaş, Süleyman (2009). 1923'den 2023'e Türkiye Cumhuriyeti Devleti Tarihi V, Inönü Dönemi Millî Şef Yönetimi ve Demokrasiye Geçiş, 1938-1950, İstanbul: Bayrak Yayınc1lık.

Koçak, Cemil (1996). Türkiye’de Milli Şef Dönemi (1938-1945), II, İstanbul: İletişim Yayınları.

Kongar, Emre (2013). Tarihimizle Yüzleşmek, İstanbul: Remzi Kitapevi.

Köşgeroğlu, Nedime (2010). Beli Kırllan Devrim, Köy Enstitüleri ve Kadın Kalemler, İstanbul: Alter Yayınları.

Kurt, Abdurrahman (2009). "Dindarlığı Etkileyen Faktörler", T.C. Uludağ Üniversitesi Illahiyat Fakültesi Dergisi, 18 (2), 1-26.

Kuşat, Ali (2001). "Eğitim ve Dinin Benlik Gelişmesiyle İlgisi”, Erciyes Üniversitesi İlahiyat Fakültesi Dergisi, Kayseri: (11), 97-104.

Kuşat, Ali (2012). “İbadetlerde Niyetin Ahlaki Gelişim Düzeyi ile İlişkisi”, ÇÜİFD Din Psikolojisi Özel Sayısı, Prof. Dr. Kerim Yavuz Armă̆anı, 12 (2), 157-183.

Lewis, Bernard, (2009). Modern Türkiye’nin Doğuşu, (Çev: Boğaç Babür Turna), Anakara: Arkadaş Yayınları.

Mahçupyan, Etyen (9 Şubat 2014). "Meselenin Adını Koyalım”, Zaman Gazetesi. 
Makal, Mahmut (2009). Köy Enstitüleri ve Ötesi, İstanbul: Literatür Yayınları.

Mardin, Şerif (2010). Türkiye'de Din ve Siyaset, İstanbul: İletişim Yayınları.

Meriç, Cemil (1996). Umrandan Uygarliğa, (Haz. Mahmut Ali Meriç), İstanbul: İletişim Yayınları.

Muallimler Birliği Mecmuası, (1925). Ankara: (4).

Ocak, Ahmet Yaşar, (1990). "Çağdaş Türk Aydını ve Yakın Tarih Perspektifi İçinde Türkiye'de İslam Gerçeği”, Kutlu Doğum Haftası, 12-17 Ekim 1989, Ankara: TDV Yayınları.

Ocak (1996). “Değişen Dünyada İslam'ın Batıya Dönük Yüzü: Günümüz Türkiye Müslümanlığına Genel Bakış”, Müslüman İmajı, (Kutlu Doğum Haftası: 1995), Ankara: TDV Yayınları.

Ok, Üzeyir (2012). “Biyografik Anlatıya Dayalı İnanç Gelişimi Biçimleri ve Nicel Ölçümler”, ÇÜIFD Din Psikolojisi Dergisi Özel Sayısı Prof. Dr. Kerim Yavuz Armağanı, 12 (2), 121-155.

Okumuş, Ejder (2002). Gösterişçi Dindarlık, İstanbul: Ark Yayınları.

Okumuş (2010). Toplumsal Değişme ve Din, İstanbul: İnsan Yayınları.

Okutan, M. Çağatan (2013). “Conservatism: Historical-Philosophical Roots”, International Journal of Economic and Administrative Studies, Year: 5(10), 127-133.

Öcal, Mustafa, (Ed.). (2008). Tanıkların Dilinden Cumhuriyet Dönemi Din Eğitimi ve Dinî Hayat (3 cilt). İstanbul: Ensar Neşriyat.

Öklem, Hüseyin G. (2008). Olayazdı, Köy Enstitüleri Yaşasaydı Türkiye Nasıl Olurdu?, Antalya: Yeniden Anadolu ve Rumeli Müdafaa-i Hukuk Yayınları.

Özdenoğlu, Şinasi (1945). "Hümanismanın Gerçek Mânası”, Yücel Aylık Sanat ve Fikir Dergisi, XVII, 97-100.

Pargament, Kenneth I., (Ocak-Haziran 2005). “Acı ve Tatlı: Dindarlığın Bedelleri ve Faydaları Üzerine Bir Değerlendirme", (Çev. Ali Ulvi Mehmedoğlu), ÇÜİFD, 5 (1), 279-313.

Perinçek, Doğu, (2007). Kemalist Devrim-2 Din ve Allah, İstanbul: Kaynak Yayınları.

Resmi Gazete, 4827, 6 Haziran 1941. 
Safa, Peyami (2011). Din, İnklap ve İrtica, İstanbul: Ötüken Yayınları.

Safa (2013). Türk İnklabına Bakışlar, İstanbul: Ötüken Yayınları.

Sakal, Fahri (2008). Çok Partili Döneme Geçişte Tek Partinin Muhalefet Anlaylşı, Samsun: Etüt Yayınları.

Sakaoğlu, Necdet (1992). Cumhuriyet Dönemi Ĕ̆itim Tarihi, İstanbul: İletişim Yayınları.

Stark, Rodney- Glock, Charles Y. (1974). American Piety: The nature of Religion Commitment, United Satates of America: University of California Press.

Subaş1, Necdet (1995). "Fundamentalizm, İslam ve Hayat", İslami Araştırmalar, VIII(3-4), 250-262.

Subaşı, (2004). Gündelik Hayat ve Dinsellik, İstanbul: İz Yayıncılık.

Şeker, Kadir (2000). İnönü Dönemi Kültür Hayatı (1938-1950), (Yayınlanmamış Doktora Tezi), Süleyman Demirel Ünivesitesi, Sosyal Bilimler Enstitüsü, Tarih Anabilim Dalı, Isparta.

Tarhan, Nevzat (2010). Asimetrik Savaş, Politik Psikoloji, İstanbul: Timaş Yayınları.

Tarhan (2010). Sosyal Psikolojisi, Sosyal Şizofreniden Toplumsal Empatiye, İstanbul: Timaş Yayınları.

“Tarihi Vesika”, (1959). İstanbul: Sebilürreşad, XII (284).

Taş, Kemaleddin (2004). "Dindarlığa Etki Eden Faktörler", Süleyman Demirel Üniversitesi Ilahiyat Fakültesi Dergisi, (13), 63-83.

Tekinalp (1998). Kemalizm, (Çev. Çetin Yetkin), İstanbul: Toplumsal Dönüşüm Yayınları.

Toker, Metin (1970). Tek Partiden Çok Partiye, İstanbul: Milliyet Yayınları.

Tonguç, İsmail Hakkı (1947). Canlandırılacak Köy, İstanbul: Remzi Kitapevi.

Topçu, Nurettin (2008). Psikoloji, (Haz: Ezel Erverdi, İsmail Kara), İstanbul: Dergah Yayınları.

Toynbee, Arnold (1991). Medeniyet Yargllanıyor, (Çev. Ufuk Uyan), İstanbul: Ağaç Yayınları.

Turam, Berna (2007). Between Islam And The State, The Politics of Engagement, California: Stanford University Press.

Turan, Osman (2005). Türkiye’de Manevi Buhran Din ve Laiklik, İstanbul: Ötüken Yayınları. 
Turhan (1969). Kültür Değişmeleri, Sosyal Psikolojik Bakımından Bir Tetkik, İstanbul: Milli Eğitim Basımevi.

Turhan, Mümtaz (1972). Garplılaşmanın Neresindeyiz?, İstanbul: Yağmur Yayınları.

Türk Dil Sözlüğü (1945). İstanbul: Cumhuriyet Basımevi.

Türkdoğan, Orhan (1996). Değişme Kültür ve Sosyal Çözülme, İstanbul: Birleşik Yayıncıllı.

Türköne, Mümtazer (1994). Modernleşme, Demokrasi ve Laiklik, Ankara: Ark Yayınları.

Vergote, Antoine (1999). Din, Inanç ve Inançsızılık, (Çev. Veysel Uysal), İstanbul: MÜ İlahiyat Fakültesi Vakfi Yayınları.

Yalçıntaş, Nevzat (2012). Türkiye'yi Yükselten Yıllar, İstanbul: İşaret Yayınları.

Yapıcı, Asım (2007). “Geleneksellik ve Modernlik Arasında Sıkışan Din Anlayışları ve Dindarlık”, Dem Dergisi, 1 (2), 24-29.

Yavuz, M. Hakan (October 2004). "Is There a Turkish Islam? The Emergence of Convergence and Consensus”, Journal of Muslim Minority Affairs, 24 (2), 213-232.

Yeşilkaya, Neşe, “Halkevleri”, Moderne Türkiye’de Siyasi Düşünce: Kemalizm, İstanbul 2011.

Yıldırım, Ergün (1995). Türkiye’nin Modernleşmesi ve İslam, İstanbul: İnsan Yayınları.

Yıldırım (1999). Değişen Din Anlayışının Sosyolojisi, (1908-1950), İstanbul: Bilge Yayınları.

Y1ldırmaz, Sinan, (2013). "Muhafazâkarlık, Türk Muhafazâkarlığg ve Peyami Safa Üzerine”, Journal of Historical Studies, 1, 9-18.

Yıldız, Fatih, Çelik, Fikret (Yaz 2012). “Türk Batıcılığının Milliyetçi- Muhafazakârlık Üzerinden Tenkidi: Erol Güngör Örneği”, Bilig, Türk Dünyası Sosyal Bilimler Dergisi, (62), 269-294,

Yı1maz, Mustafa (1998). “İnönü Döneminde Bakanlar Kurulu Kararı ile Yasaklanan Yayınlar 1938-1945”, Türk Kültürü Araştırmaları Dergisi, Dr. Orhan Fuat Köprülü’ye Armağan, Ankara.

Yiğit, Ali Ata (1992.) İnönü Dönemi Eğitim ve Kültür Politikası, İstanbul: Boğaziçi Yayınları.

Yücel, Hasan Ali (1974). Kültür Üzerine Düşünceler, Ankara: Türkiye İş Bankası Kültür Yayınları.

Zeyrek, Şerafettin (1987). Türkiye’de Halkevleri 1032-1951, Ankara: Anı Yayıncılık. 